\title{
Competence Profile of Indonesian Food Chefs in Malang Based on Educational Background
}

\author{
Rina Rifqie Mariana, Nunung Nurjanah \\ Industrial Technology Department, Engineering Faculty \\ Universitas Negeri Malang \\ Malang, Indonesia \\ rina.rifqie.ft@um.ac.id
}

\author{
Ahmad Dardiri \\ Civil Engineering Department, Engineering Faculty \\ Universitas Negeri Malang \\ Malang, Indonesia
}

\begin{abstract}
This study aimed to identify the professional competence of chefs in traditional Indonesian restaurants in Malang city. The study was conducted in two stages involving 12 selected restaurants. The first stage was identifying the profile of chefs, while the second stage consisted of in-depth interviews and FGD with some Indonesian restaurant owners, head chefs, and the administrators of Indonesian Chef Association (ICA) in Malang. Results showed that only 36.7\% chefs (65 out of 177) have some background in culinary education (culinary vocational high school graduates). The rests, $63.3 \%$, were chefs without any background in culinary education (nonlinear), comprising graduates of junior high schools, senior high schools, and vocational high schools majoring in computer, mechanical engineering, commerce, and others. Interviews and FGDs with the research participants suggest that chefs' characters (creativity, responsibility, passion, and determination) and work experience are considered more important than educational background. The findings are somewhat different from some theories related to the importance of formal and non-formal education in the development of the culinary sector.
\end{abstract}

Keywords-chef, competence, education

\section{INTRODUCTION}

Chengdu, a city in China's Sichuan province, has been officially named a UNESCO Creative City of Gastronomy in 2010 in global recognition of promoting traditional Sichuan dishes in line with international quality standards [1]. Chengdu has a unique culinary culture in which the potential of traditional foods is always explored by skilled chefs who use indigenous ingredients and techniques with a touch of creativity and expertise. According to [1], there are more than 2000 super chefs and nearly 300 national-level master chefs in Chengdu. This city has the only university in China that focuses on culinary arts education and research called Sichuan Higher Institute of Cuisine. There is also Chengdu Sichuan Cuisine Museum which displays than 3,000 pieces of collections featuring Sichuan dishes from past to present days. Chengdu also has a Sichuan Cuisine Museum featuring over 3,000 varieties of food collections, ranging from the most ancient to the most modern. As stated by [2], formal and non-formal culinary education affect chefs' ability to judge the quality food products in terms of aroma, texture, or colour. Education and practical experience greatly affect how a chef blends ingredients and identifies the quality and taste of food [3] [4] [5]. According to [6] creativity is the ability to transform cultural tradition, shifting from tangible heritage to greater culture. Creative culinary industry should develop unique and new products by coming up with an innovative menu selection with aesthetic appeal [7].

Thailand can also be considered as an excellent example of best practices in culinary tourism. Traditional Thai food is popular in Europe and America. The Thai government had launched the "Thai Kitchen to the World" programme, in which hotels and restaurants were encouraged to promote Thai dishes worldwide by creating world-class traditional culinary products. In Indonesia, on the other hand, 4- and 5star hotels and restaurants often prefer serving foreign dishes over traditional ones. As stated [8], hotels and restaurants in Indonesia should take considerable effort to promote and popularise traditional food to the world.

Indonesia is home to rich and unique cultural heritage and abundant natural resources. Each of the 33 provinces in Indonesia has its own popular dishes and specialities. Most of the dishes are not only bursting with nutrients but also intense aroma and flavour, and thus if packed and presented well, they can open up opportunities to achieve global recognition [9]. Rendang, fried rice, and satay are Indonesian dishes which have been ranked among the World's 50 Best Foods by CNN. This kind of thing is exactly what needs to be maintained and developed. Producing high-quality dishes is the key to success in the international culinary industry. To this end, skilled and creative chefs equipped with sufficient culinary knowledge and practical experience through training and other forms of education. [10] [11] stated that a restaurant's success in maintaining services excellence to satisfy customers is highly dependent on the competence of the chefs. In other words, it is necessary to continuously upgrade chefs' culinary skills and hands-on experience through vocational culinary training and other development programmes. A chef should not only make delicious and healthy food but also ensure food safety and have a good aesthetic sense for food presentation [12]. The availability of competent, productive, and creative human resources is related to the development of competitive culinary products. Education, particularly higher education, plays a vital role in the provision of professional human resources to meet workforce needs, as stated in Law No. 12 on Higher Education.

The failure of Malang's culinary sector to create the city as a UNESCO Creative City of Gastronomy was due to lack of accurate and comprehensive data about the potential of culinary tourism in Malang and the development strategy of 
culinary subsectors such as the creativity of chefs in Malang. According to [13] to develop traditional Indonesian food that can compete at the international level, several elements needs improvement, namely: 1) optimal government support, 2) availability of indigenous materials, 3 ) number of Indonesian restaurants domestically and internationally, 4) chefs with good knowledge about indigenous cooking skills, ingredients, and culture. Indonesian chefs still lack cooking skills in preparing traditional recipes of the archipelago. Many young chefs master western cuisines more than traditional ones; this is attributed to their limited knowledge about traditional culinary practices. The success of creative culinary depends on the quality of human resources. According to the Ministry of Trade of the Republic of Indonesia, creative industry is an industry derived from the utilisation of creativity, skills, and talents to improve welfare and create employment. Based on the above background, it is necessary to investigate the profile of chefs cooking traditional dishes in Malang, as an effort to support Malang as a Creative City of Gastronomy by UNESCO [14].

\section{METHOD}

The study was conducted in two stages. The first stage was identifying the profile of all chefs in 12 selected traditional Indonesian restaurants in Malang, including sex, age, years of experience, education, and vocational training. $30 \%$ of chefs from each restaurant were also interviewed; those with and without relevant educational background and in-service training. In the second phase, in-depth interviews were carried out with the administrators of Indonesian Chef Association (ICA) in Malang and some Indonesian restaurant owners in Malang. They required providing information related to the competence of chefs and the constraints and efforts in the development of chefs in Malang.

\section{RESULT AND DISCUSSION}

\section{A. Glimpse of Traditional Indonesia Restaurants in Malang}

Based on data released by the Department of Industry and Trade of Malang, there are 508 Indonesian restaurants in Malang, comprising different restaurant classes: kencana (upper class), selaka (middle class), and gangsa (lower class). The 12 kencana-class restaurants under study are restaurants that only serve traditional Indonesian dishes, no western or other foreign food. All of the restaurants were established at least 10 years ago, some even opened 30 years ago, and still going strong. By serving authentic tradition meals in an elegant-traditional setting with ethnic-style tableware, these restaurants attract diners who seek authentic cultural dining experience (see Fig. 1 and 2)

As shown in Fig. 1 and 2, the restaurants feature the ambience of Javanese culture with Javanese traditional songs accompanied by strains of Javanese gamelan sounds. They serve Javanese food in a traditional Javanese way, using Javanese-style tableware. These elements create an oldfashioned atmosphere of Javanese life and culture.

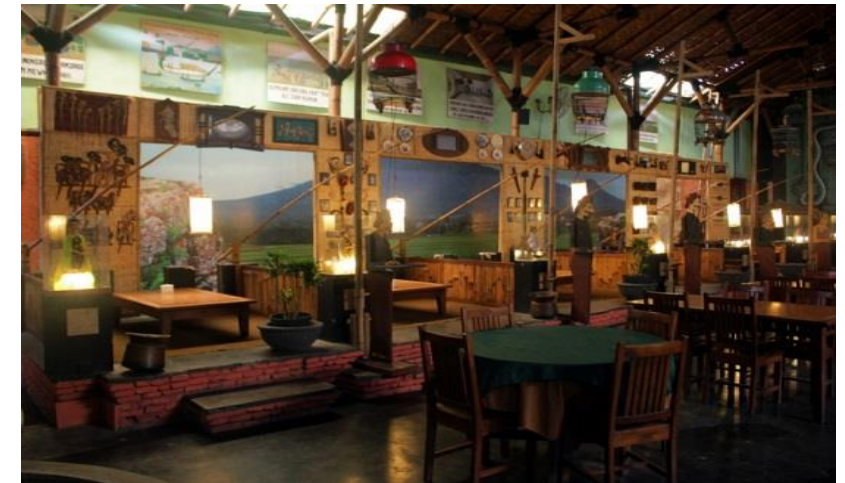

Fig. 1. One of the restaurant in Malang with an authentic Javanese style interior and traditional ambience

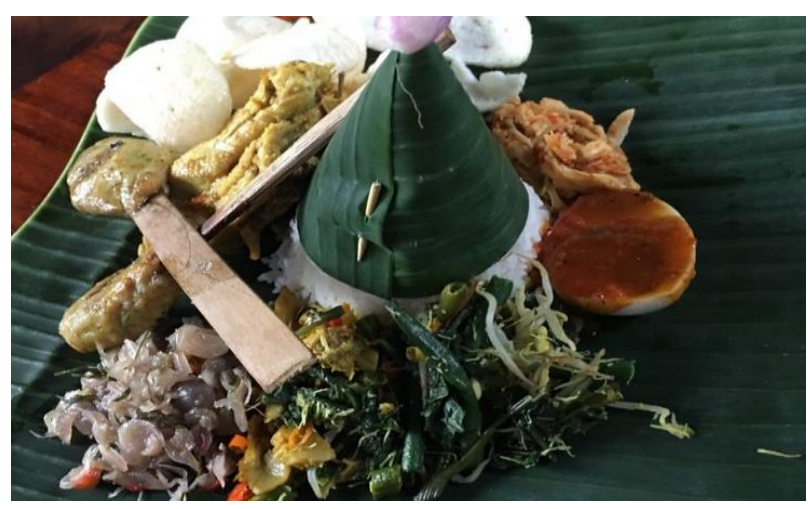

Fig. 2. Nasi Campur, one of the most popular traditional dishes of Indonesia

Table 1 shows the description of the formal education background of chefs in Indonesian restaurants in Malang. Table 1 shows the educational background of chefs in the 12 restaurants under study. Only $36.7 \%$ or 65 out of 177 chefs have some background in culinary education (linear), i.e. $35.5 \%$ culinary vocational high school graduates and $1.2 \%$ diploma graduates in tourism. The rest, 63\%, are chefs without any background in culinary education (nonlinear), comprising graduates of junior high schools, senior high schools, and vocational high schools majoring in computer, mechanical engineering, commerce, and others. Based on the interviews with 12 head chefs/owners, eight people from the 12 restaurants revealed almost the same thing. Having some culinary background is important since the chefs will understand the basics of food processing. However, chefs' characters are even necessary. Chefs with high creativity, responsibility, determination, productivity, responsiveness, and passion are valuable assets. The owner of one restaurant under study stated that only 4 out of 16 chefs have a linear educational background. As the time passes by, however, the competence of chefs without culinary background cannot be distinguished from those with a culinary education. Recipes and seasonings are prepared first. The chefs just cook based on the predetermined amount of seasoning. Food processing stages and techniques are taught to new chefs through training and mentoring for 1 week. In general, they can adjust themselves within a short time. Each restaurant has a standard for plating and serving food to customers. The head chef of one restaurant under study is only a senior high school graduate but working and dedicating himself for 7 
years has proven his excellent skills in cooking Indonesian dishes. In fact, the building blocks of becoming a head chef are creativity, determination, and skills to process food until serving.

TABLE I. EDUCATIONAL BACKGROUND OF CHEFS OF INDONESIAN CUISINE IN MALANG

\begin{tabular}{|c|c|c|c|c|c|c|c|c|}
\hline \multirow{2}{*}{$\begin{array}{c}\text { Restau } \\
\text { rant }\end{array}$} & \multirow{2}{*}{$\begin{array}{c}\text { No. } \\
\text { of } \\
\text { Chef } \\
\text { s }\end{array}$} & \multicolumn{2}{|c|}{$\begin{array}{l}\text { Educational } \\
\text { Background }\end{array}$} & \multicolumn{5}{|c|}{ Last Education } \\
\hline & & $\begin{array}{l}\text { Line } \\
\text { ar }\end{array}$ & $\begin{array}{l}\text { Non- } \\
\text { linear }\end{array}$ & $\begin{array}{c}\text { Culinary } \\
\text { Vocational } \\
\text { High School }\end{array}$ & $\begin{array}{c}\text { Diploma in } \\
\text { Tourism }\end{array}$ & $\begin{array}{c}\text { Junior } \\
\text { High } \\
\text { School }\end{array}$ & $\begin{array}{c}\text { Senior } \\
\text { High } \\
\text { School }\end{array}$ & Other \\
\hline A & 15 & 7 & 8 & 7 & 0 & 4 & 3 & 1 \\
\hline B & 21 & 12 & 9 & 11 & 1 & 6 & 3 & 0 \\
\hline $\mathrm{C}$ & 11 & 3 & 8 & 3 & 0 & 3 & 3 & 2 \\
\hline D & 30 & 12 & 18 & 12 & 0 & 6 & 7 & 5 \\
\hline$E$ & 18 & 6 & 12 & 6 & 0 & 4 & 5 & 3 \\
\hline $\mathrm{F}$ & 24 & 11 & 13 & 10 & 1 & 6 & 5 & 2 \\
\hline $\mathrm{G}$ & 5 & 0 & 5 & 0 & 0 & 3 & 2 & 0 \\
\hline $\mathrm{H}$ & 6 & 0 & 6 & 0 & 0 & 4 & 2 & 0 \\
\hline $\mathrm{I}$ & 9 & 3 & 6 & 3 & 0 & 2 & 2 & 2 \\
\hline $\mathrm{J}$ & 12 & 4 & 8 & 4 & 0 & 3 & 4 & 1 \\
\hline $\mathrm{K}$ & 16 & 4 & 12 & 4 & 0 & 3 & 5 & 4 \\
\hline $\mathrm{L}$ & 10 & 3 & 7 & 3 & 0 & 2 & 3 & 2 \\
\hline Tot. & 177 & 65 & 112 & 63 & 2 & 46 & 44 & 22 \\
\hline$\%$ & 36.7 & 63.3 & 35.6 & 1.1 & 26 & 24.9 & 12.4 & 36.7 \\
\hline
\end{tabular}

TABLE II. IDENTITy OF CHEFS IN MALANG By SEX AND AGE

\begin{tabular}{|c|c|c|c|c|c|c|c|c|c|c|}
\hline \multirow{2}{*}{$\begin{array}{c}\text { Restaura } \\
\text { nt }\end{array}$} & \multirow{2}{*}{$\begin{array}{l}\text { No. of } \\
\text { Chefs }\end{array}$} & \multicolumn{2}{|c|}{ Sex } & \multicolumn{9}{|c|}{ Age } \\
\hline A & 15 & 10 & 5 & 2 & 1 & 2 & 4 & 2 & 2 & 2 \\
\hline B & 21 & 15 & 6 & 3 & 2 & 2 & 1 & 4 & 3 & 6 \\
\hline C & 11 & 5 & 6 & 1 & 2 & 1 & 1 & 2 & 1 & 3 \\
\hline D & 30 & 16 & 14 & 3 & 3 & 2 & 2 & 6 & 6 & 8 \\
\hline E & 18 & 12 & 6 & 1 & 1 & 1 & 3 & 3 & 4 & 5 \\
\hline F & 24 & 12 & 12 & 0 & 2 & 3 & 5 & 4 & 6 & 4 \\
\hline G & 5 & 1 & 4 & 0 & 0 & 0 & 0 & 0 & 2 & 3 \\
\hline H & 6 & 3 & 3 & 0 & 0 & 0 & 0 & 0 & 3 & 3 \\
\hline I & 9 & 5 & 4 & 0 & 2 & 1 & 0 & 0 & 2 & 4 \\
\hline J & 12 & 8 & 4 & 4 & 2 & 2 & 0 & 3 & 1 & 0 \\
\hline K & 16 & 10 & 6 & 1 & 1 & 2 & 2 & 4 & 3 & 3 \\
\hline L & 10 & 6 & 4 & 2 & 3 & 0 & 0 & 1 & 2 & 2 \\
\hline Tot. & 177 & 103 & 74 & 17 & 19 & 16 & 18 & 29 & 35 & 43 \\
\hline \% & & 58 & 42 & 9.6 & 10.7 & 9.0 & 10.2 & 16.4 & 19.8 & 24.3 \\
\hline
\end{tabular}

Chefs are not fully involved in assembling the spice blends of dishes due to the following reasons.

"We have to keep our secret recipes. In addition, standardisation of taste is expected. It is, therefore, crucial to ensure precise measurement of spices. A different chef can result in a different taste, which may disappoint consumers. We keep our secret formulas from being made public; even our chefs have no idea of them. By doing so, we prevent chefs from stealing our recipes and replicating them elsewhere".

The above statement is quite consistent with 8 other chefs. One of them is the chef at restaurant $\mathrm{L}$.

"I have worked as a chef in this restaurant for 6 years. I do not know the secret formula of fish dishes since the spice mix is always packed and ready to use. I just add sliced chillies or other fresh seasonings with a predetermined measurement. I should follow the rules of presenting food on the plate which are already set. Any changes or additions to the menu and the plating procedure are made by the head chefs."

The above statement suggests that head chefs are the ones who have to be creative because they are in charge of determining the quality of food. The importance of creativity in head chefs is in line with [15] stating that restaurant managers and chefs must be able to stay innovative and attract new customers by satisfying the increasingly sophisticated demands of consumers. Currently, restaurant consumers, in particular, are looking for new and unique experiences. To meet the demands, innovation in the culinary industry should be encouraged. There should always be culinary creativity which involves the creation of new dishes or ideas. [15] [16] emphasised the importance of chef's work competence in order to create innovative products and offer good services to customers. According to interviews with restaurant owners, the chefs have not been supported to participate in professional training. This is related to work culture and job description given to chefs whose creativity is controlled by a head chef. As stated by [17] [18] [19], nonconducive work environment can hinder chefs' attempts to foster creativity. Chefs in Indonesia, particularly in Malang, get limited opportunities to develop their culinary skills, unlike those in Thailand, Vietnam, and Spain. Chefs of traditional dishes in those countries are often given chances to develop their cooking skills through professional training and vocational culinary training [12]. As suggested by [20] [21], culinary principles focus on creativity, art, ingredient 
availability and quality, and professional cooking techniques and equipment.

Most Indonesian food chefs in Malang consider educational background not very important. Individual characters and work experience are far more crucial to become a professional chef. This was supported by a head chef of a popular restaurant in Malang who graduated from a culinary vocational high school and has worked in the culinary industry for 26 years. He stated that:

"I graduated from vocational high school majoring in culinary 28 years ago, and have worked for 26 years in the culinary field sta. I started as a server in a restaurant, and then I worked in hotels, ranging from economy hotels to 5-star hotels. Experiences shape my vision to be creative in the field of culinary. I often attended culinary competitions organised by government and private institutions. The more I create culinary works, the more I love the culinary world. I am 56 now, and I never stop to come up with creations in developing traditional Indonesian cuisine that can be enjoyed not only by domestic dining customers but also foreigners who come to our restaurant. Moreover, with the advancement of cooking technology and equipment, I can process food much more easily; cooking is not only about formulating recipes, but also using proper processing techniques."

The above statement was corroborated by 6 members of Indonesian Chef Association (ICA) participated in the Focus Group Discussion (FGD). It can be concluded that work experience, individual characters including creativity and passion, and competition experience are much more meaningful than the linearity of educational background. As found by [22], 32 chefs working in hotels in Salvador, Brazil stated that their knowledge of food processing and food sanitation were influenced by training and development experiences. In Thailand, most chefs master cooking skills through television, culinary magazines, and guidebooks [12], meaning that they learn on their own initiative and learning motivation comes from within. Also, many television programmes and magazines in Vietnam and Spain provide resources for chefs to improve their traditional cooking skills [23]. Television is indeed a great medium to popularise local traditional foods, and consequently, culinary tourism has increasingly well-known since the end of the 20th century [24]. The media has also encouraged the development of global communities around food and gastronomy [25].

As an initial effort for improvement, Indonesia should maximise the role of vocational education to prepare graduates to become professional workers in the field of culinary. Theoretically, education is an element that should not be overlooked in becoming culinary professionals. Education serves as a means of generating creative people in the culinary industry [1]. Thailand, for instance, is one of the countries that already have formal educational institutions that specifically teach the traditional culinary practices but through the modern learning process. Moreover, Le Cordon Bleu Dusit, one of the best culinary schools in the world, works with the government to open a Professional Thai Cuisine Diploma Program. The instructional materials are based on a comprehensive Thai Cuisine curriculum consisting of over 200 traditional Thai recipes [26]. This aims to produce chefs who are reliable, professional and equipped with practical skills to create traditional Thai food for future culinary business in the country or overseas.
Indonesia should learn from other countries like Thailand to improve its human resources who lack creativity and innovation capability; it is a serious problem in the creative industry that affects adversely to competitiveness and business performance [27].

\section{CONCLUSION}

The formal educational background of $63 \%$ or 112 out of 177 Indonesian food chefs in Malang is not linear, meaning that they do not have any background in culinary and tourism education. Most of them are junior high school graduates aged between 46 or above who have long working experience. The interviews and FGDs with restaurant owners, head chefs, and the administrators of Indonesian Chef Association (ICA) in Malang suggest that skilled and reliable chefs are those with creativity, passion, determination, and work experience. Formal culinary education is important, but the above characters are even necessary. In particular, the creativity of head chefs is the key to the success of Indonesian restaurants in Malang.

\section{REFERENCES}

[1] M. Lazuardi and M. S. Triadi, Rencana Pengembangan Kuliner Nasional 2015-2019. Jakarta: PT. Republik Solusi, 2015.

[2] N. K. Byrnes, C. R. Loss, and J. E. Hayes, "Perception of chemesthetic stimuli in groups who differ by food involvement and culinary experience," Food Qual. Prefer., vol. 46, pp. 142-150, 2015.

[3] J. Kennedy and H. Heymann, "Projective mapping and descriptive analysis of milk and dark chocolates," J. Sens. Stud., vol. 24, no. 2, pp. 220-233, 2009.

[4] M. A. Nestrud and H. T. Lawless, "Perceptual mapping of apples and cheeses using projective mapping and sorting," J. Sens. Stud., vol. 25, no. 3, pp. 390-405, 2010.

[5] D. C. E. Roberts, "Food Authenticity," Br. Food J., vol. 96, no. 9, pp. 33-35, Oct. 1994.

[6] G. Richards, "Creativity and tourism," Ann. Tour. Res., vol. 38, no. 4, pp. 1225-1253, Oct. 2011.

[7] T. A. Hagadone and R. K. Grala, "Business clusters in Mississippi's forest products industry,” For. Policy Econ., vol. 20, pp. 16-24, Jul. 2012.

[8] B. Winarno, Ragam Wisata Kuliner. Jakarta: Pustaka Utama, 2007.

[9] R. Rifqie Mariana, L. Hidayati, and S. Soekopitojo, "Implementing the HACCP system to the production of Bakso Malang-Indonesia," J. Culin. Sci. Technol., pp. 1-22, 2018.

[10] S. Richardson, "Undergraduates' perceptions of tourism and hospitality as a career choice,” Int. J. Hosp. Manag., vol. 28, no. 3, pp. 382-388, 2009.

[11] J. Pratten and B. O'Leary, "Addressing the causes of chef shortages in the UK," J. Eur. Ind. Train., vol. 31, no. 1, pp. 68-78, 2007.

[12] L. Pang, "The training and creativity of professional chefs: Stoking the imagination in global gastronomic discourse," Appetite, vol. 119, pp. 48-53, 2017.

[13] I. Maulana and A. R. Prasetia, "STRATEGI KREATIF USAHA KULINER INDONESIA UNTUK MEMPERLUAS PASAR KE KAWASAN ASIA TENGGARA DALAM ERA MASYARAKAT EKONOMI ASEAN (MEA)."

[14] UNESCO, "UNESCO Creative Cities Network 2017: Applicant's Handbook." UNESCO, 2017.

[15] J.-S. Horng and M.-L. Hu, "The mystery in the kitchen: Culinary creativity," Creat. Res. J., vol. 20, no. 2, pp. 221-230, 2008.

[16] K. Birdir and T. E. Pearson, "Research chefs' competencies: a Delphi approach," Int. J. Contemp. Hosp. Manag., vol. 12, no. 3, pp. 205209, 2000.

[17] G. A. Fine, Kitchens: The culture of restaurant work. Univ of California Press, 2008.

[18] H. McGee, On food and cooking: the science and lore of the kitchen. Simon and Schuster, 2007. 
[19] R. N. Robinson and L. G. Beesley, "Linkages between creativity and intention to quit: An occupational study of chefs," Tour. Manag., vol. 31, no. 6, pp. 765-776, 2010.

[20] N. Myhrvold, C. Young, and M. Bilet, Modernist cuisine. Taschen Cologne, Germany, 2011.

[21] S. Fraser and P. Lyon, "Chef Perceptions of Modernist Equipment and Techniques in the Kitchen," J. Culin. Sci. Technol., pp. 1-18, 2017.

[22] L. T. Rebouças, L. B. Santiago, L. S. Martins, A. C. R. Menezes, M. da P. N. Araújo, and R. C. de Castro Almeida, "Food safety knowledge and practices of food handlers, head chefs and managers in hotels' restaurants of Salvador, Brazil," Food Control, vol. 73, pp. 372-381, 2017

[23] J. Johnston and S. Baumann, "Democracy versus distinction: A study of omnivorousness in gourmet food writing," Am. J. Sociol., vol. 113, no. 1, pp. 165-204, 2007.
[24] A. Carruthers, "Indochine chic: Why is Vietnamese food so classy in Singapore?(Respond to this article at http://www. therai. org. uk/at/debate)," Anthropol. Today, vol. 28, no. 2, pp. 17-20, 2012.

[25] R. Ferguson and C. Olofsson, "Science parks and the development of NTBFs - location, survival and growth," J. Technol. Transf., vol. 29, no. 1, pp. 5-17, 2004.

[26] "Professional Thai Cuisine | Le Cordon Bleu Dusit." [Online]. Available: https://www.cordonbleu.edu/thailand/professional-thaicuisine/en. [Accessed: 10-Apr-2018].

[27] M. Mulyana, "Peningkatan Kapabilitas Inovasi, Keunggulan Bersaing dan Kinerja melalui Pendekatan Quadruple Helix: Studi Pada Industri Kreatif Sektor Fashion,” J. Technol. Manag., vol. 13, no. 3, pp. 304321, 2014. 